\title{
Citric acid wastewater as electron donor for biological sulfate reduction
}

\author{
Alfons J. M. Stams • Jacco Huisman • \\ Pedro A. Garcia Encina • Gerard Muyzer
}

Received: 4 March 2009/Revised: 31 March 2009 /Accepted: 31 March 2009 / Published online: 28 April 2009

(C) The Author(s) 2009. This article is published with open access at Springerlink.com

\begin{abstract}
Citrate-containing wastewater is used as electron donor for sulfate reduction in a biological treatment plant for the removal of sulfate. The pathway of citrate conversion coupled to sulfate reduction and the microorganisms involved were investigated. Citrate was not a direct electron donor for the sulfate-reducing bacteria. Instead, citrate was fermented to mainly acetate and formate. These fermentation products served as electron donors for the sulfate-reducing bacteria. Sulfate reduction activities of the reactor biomass with acetate and formate were sufficiently high to explain the sulfate reduction rates that are required for the process. Two citrate-fermenting bacteria were isolated. Strain R210 was closest related to Trichococcus pasteurii (99.5\% ribosomal RNA (rRNA) gene sequence similarity). The closest relative of strain S101 was Veillonella montepellierensis with an rRNA gene sequence similarity of $96.7 \%$. Both strains had a complementary substrate range.
\end{abstract}

\footnotetext{
A. J. M. Stams ( ()

Laboratory of Microbiology, Wageningen University, Dreijenplein 10, $6703 \mathrm{HB}$,

Wageningen, The Netherlands

e-mail: fons.stams@wur.nl

J. Huisman

Paques B.V.,

Balk, The Netherlands

P. A. Garcia Encina

Department of Chemical Engineering and Environmental

Technology, University of Valladolid,

Valladolid, Spain

G. Muyzer

Department of Biotechnology, Delft University of Technology,

Delft, The Netherlands
}

Keywords Desulfurization · Sulfate reduction . Citrate fermentation $\cdot$ Trichococcus $\cdot$ Veillonella

\section{Introduction}

The biological sulfur cycle plays an important role in nature. In addition, the biological sulfur cycle can be applied in biotechnology to remove and recover sulfur from wastewater and gas (Buisman et al. 1989; Janssen et al. 1995a, 2001; Lens et al. 1998; Muyzer and Stams 2008). Chemolithotrophic sulfide-oxidizing bacteria oxidize sulfide to sulfate, but under oxygen-limiting conditions, mainly elemental sulfur is formed (Janssen et al. 1995a). This property of sulfide-oxidizing bacteria is applied to convert hydrogen sulfide in biogas or natural gas to elemental sulfur (Janssen et al. 2001). Presently, about 100 of such full-scale installations are in operation worldwide. Biological processes can also be applied for the removal of sulfate from wastewater (Buisman et al. 1989; Johnson 2000; Lens et al. 1998). The sulfate-containing stream is led into an anaerobic bioreactor, in which, by the activity of dissimilatory sulfatereducing bacteria, hydrogen sulfide is formed. In a second micro-aerobic bioreactor, sulfide-oxidizing bacteria then oxidize sulfide to elemental sulfur. This biological sulfate removal process is an attractive and economical feasible alternative for the well-known lime process for flue gas desulfurization, in which gypsum is formed (Hulshoff Pol et al. 2001; Janssen et al. 2001). Presently, a full-scale biological sulfate removal installation is in operation with a capacity to produce $12 \mathrm{t}$ of sulfur per day (www.paques.nl). The biological process is operated at low temperature, and a citrate-containing wastewater stream is used as electron donor for biological sulfate reduction. 
Dissimilatory sulfate-reducing bacteria are able to use a wide variety of organic compounds as electron donor for sulfate reduction (Hansen 1994; Muyzer and Stams 2008; Widdel and Hansen 1992). Hydrogen, formate, lactate, malate, and ethanol are well known substrates for Desulfovibrio, Desulfomicrobium, and Desulfotomaculum species. In general, these bacteria oxidize organic compounds incompletely to acetate. Short chain and long chain fatty acids are substrates for different genera of sulfate-reducing bacteria like Desulfobulbus, Desulfococcus, Desulfosarcina, and Desulfonema. Acetate is only a good electron donor for some specialized bacteria like Desulfobacter postgatei and Desulfobacca acetoxidans (Dar et al. 2007; Oude Elferink et al. 1994, 1999). Hydrogen-rich gas is being used as electron donors for biological sulfate reduction at low temperature at full scale (Van Houten et al. 2006; Weijma et al. 2002), while at moderately thermophilic conditions $\left(65^{\circ} \mathrm{C}\right)$, methanol was found to be an excellent electron donor for biological sulfate reduction as well (Weijma and Stams 2001; Weijma et al. 2000).

In a recent study, methanogenesis and sulfate reduction with citrate was studied (Gámez et al. 2008), but citrate is not a known common substrate for sulfate-reducing bacteria. In fact, citrate is rarely tested as growth substrate for newly isolated species. Desulfovibrio oxamicus is able to grow with citrate (López-Cortés et al. 2006), while Desulfomicrobium apsheronum was tested but was not able to grow with citrate (Rozanova et al. 1988). The aim of the present study was to elucidate the pathway of citrate conversion coupled to sulfate reduction in the above-mentioned fullscale bioreactor and to identify the microorganisms involved. We mainly focused our research on the conversion of citrate and the microorganisms involved. The sulfatereducing community of the starting sludge had been analyzed previously (Dar et al. 2007). This sludge contained different types of sulfate-reducing bacteria, including bacteria from the genera Desulfovibrio/Desulfomicrobium, Desulfobulbus, and Desulfobacca.

\section{Materials and methods}

\section{Reactor sludges}

The samples originate from a biological sulfate reduction installation at Yixing (People's Republic of China). The sulfate-reducing bioreactors were started up with sludge from a sulfate-reducing bioreactor from a chemical plant located at Emmen, The Netherlands. The installation is operated at low temperature. The wastewater to be treated is mixed with a citrate-containing waste stream and fed to three anaerobic bioreactors, in which sulfate is reduced to sulfide. The granular sludge bed reactors are equipped with internal settlers for biomass retention. They are operated at a hydraulic retention time of approximately $6 \mathrm{~h}$ and an influent flow rate of around $800 \mathrm{~m}^{3} / \mathrm{h}$, depending on the availability of the wastewater. The total reactor volume was approximately $5,000 \mathrm{~m}^{3}$. There is no active sludge management (e.g., sludge harvesting) as the slow growth rate of anaerobic bacteria results in a small biomass production. The biomass entered with the feed stream and was washed-out with the effluent. Consequently, a reliable sludge age cannot be determined. The effluent sulfide concentration of the anaerobic bioreactors is maintained at $150 \mathrm{mg} / \mathrm{l}$ or higher. Methanogenesis did not occur. In the overall process, the dissolved sulfide is converted into elemental sulfur in an aerobic bioreactor with air as oxidation agent. The elemental sulfur is removed from the liquid by gravity settling. These two steps are not of relevance for this study.

Two sludges from the full-scale reactors were used in this study; sludge $\mathrm{S}$ was taken near the influent point of the reactor, while sludge $\mathrm{R}$ was from the central part of the reactor. The biomass in the reactor was not homogeneous in appearance. Sludge R had a more compact structure than sludge $\mathrm{S}$. The dry weight content of sludge $\mathrm{R}$ and sludge $\mathrm{S}$ was about $3.9 \%$ and $0.8 \%$, respectively, and the volatile suspended solids (VSS, a measure of organic carbon) content was about $3.0 \%$ and $0.2 \%$, respectively. The differences in dry weight and VSS content of the sludges corresponded rather well with the difference in cell numbers determined by direct counting by microscopy. The cell numbers were about $3.10^{11}$ and $5.10^{10}$ cells per milliliter for sludge $\mathrm{R}$ and $\mathrm{S}$, respectively.

Media and growth conditions

A bicarbonate-buffered mineral medium supplemented with $0.05 \mathrm{~g} / 1$ yeast extract was prepared as described previously (Stams et al. 1993). This medium was used for the activity tests with the sludges and for the enrichment and description of the bacteria. Routine cultivation of the strains was carried out in 117-ml serum bottles with $50 \mathrm{ml}$ medium or in 28-ml tubes with $10 \mathrm{ml}$ medium, and a $\mathrm{N}_{2} / \mathrm{CO}_{2}(80: 20)$ gas phase at a pressure of $170 \mathrm{kPa}$. Organic substrates were supplied at a concentration of 10 or $20 \mathrm{mM}$ and where indicated sulfate at a concentration of $20 \mathrm{mM}$. Incubations were done statically at $30^{\circ} \mathrm{C}$.

\section{Substrate conversion by sludges}

To determine the sulfate reduction activity, $0.5-\mathrm{ml}$ sludge $\mathrm{R}$ was inoculated in duplo in $50 \mathrm{ml}$ medium with $20 \mathrm{mM}$ sulfate and different organic substrates. In time, samples were taken to determine the sulfide concentrations. Controls were included without electron donor and without 
sulfate. Conversion and product formation from citrate was determined using $0.05 \mathrm{ml}$ of sludge $\mathrm{R}$ in $50 \mathrm{ml}$ medium with and without sulfate. Samples were taken in time and analyzed for organic acids. To get an impression of the abundance of different groups of bacteria, serial dilutions of suspensions of sludge $\mathrm{R}$ and sludge $\mathrm{S}$ were made in media with different substrates. The sludges were suspended by taking a sample by syringe and pressing the sample repeatedly back into the bottle with medium using needles with different sizes. The growth tests were done in 28-ml tubes. The incubation temperature was $30^{\circ} \mathrm{C}$.

\section{Isolation and characterization of strains}

Strain R210 was isolated from the above enrichment of sludge R with $10 \mathrm{mM}$ citrate without sulfate. Strain S101 was isolated from the highest dilution with growth of sludge $\mathrm{S}$ in media with $10 \mathrm{mM}$ citrate without sulfate. Pure cultures were obtained by repeated dilution in citrate-media using, each time, the highest dilution with growth. These incubations were done in 28-ml tubes with $10 \mathrm{ml}$ medium and $1 \mathrm{ml}$ of different dilutions of inoculum. Dilutions were made in tubes containing $9 \mathrm{ml}$ medium without substrate or sulfate. Purity was confirmed by microscopic observation after growth with different substrates. When grown with citrate, strain R210 and strain S101 formed typical crooked chains of cocci. When grown with sugars, strain R210 consisted of cocci and duplo-cocci.

Substrate tests were done in 28-ml tubes with $10 \mathrm{ml}$ medium. Growth substrates were tested at the indicated concentrations. Growth was determined by the increase in optical density at $660 \mathrm{~nm}$, substrate conversion, and product formation. Electron acceptor utilization was tested by determination of product formation from citrate, and in the case of iron (III), by color change of the medium.

For phylogenetic analysis of the isolated strains, cells of 10-ml cultures were concentrated by centrifugation. Genomic DNA was extracted from the cells using the Ultraclean Soil DNA Extraction kit (Mo Bio Laboratories, West Carlsbad, CA, USA) according to the manufacturer's instructions. The nearly complete $16 \mathrm{~S}$ ribosomal RNA (rRNA) gene was amplified using primers GM3F and GM4R (Muyzer et al. 1995). Polymerase chain reaction products were purified and sequenced by a commercial company (BaseClear, Leiden, The Netherlands). The sequences were first compared to sequences stored in the GenBank using the blastn algorithm (http://www.ncbi.nlm.nih.gov/BLAST). Subsequently, they were imported into the ARB database (Ludwig et al. 2004), aligned, and added to a phylogenetic tree using the QUICK_ADD_TO_EXISTING_TREE tool. The alignment was further corrected by eye, and a tree was calculated using the neighbor-joining algorithm with Felsenstein correction. The rRNA gene sequences of strain R210 and S101 are deposited in GenBank/EMBL/DDBJ under the accession numbers FJ374769 and FJ374768, respectively.

Analytical methods

Organic acids were measured by high-performance liquid chromatography, and hydrogen and methane were measured by gas chromatography, as described previously (Stams et al. 1993). Formate was analyzed colorimetrically using the method described by (Lang and Lang 1972). Sulfide was analyzed by the method of (Trüper and Schlegel 1964). The VSS content of the sludges was determined from the difference in dry weight (drying overnight at $\left.105^{\circ} \mathrm{C}\right)$ and ash content $\left(2 \mathrm{~h}\right.$ at $\left.600^{\circ} \mathrm{C}\right)$.

\section{Results}

Sulfate reduction activity of the reactor sludge

The physical appearance of sludge samples at the influent point of the reactor and in the central part of the reactor suggested that citrate degradation and sulfate reduction were not directly coupled. When incubated unfed sludge $\mathrm{R}$ had a higher sulfate-reducing activity than sludge $\mathrm{S}$ (results not shown). The sulfate reduction activity of sludge $\mathrm{R}$ from the anaerobic reactor was determined with different substrates over a period of 3 days. The initial sulfide production activity of that sludge without added substrates was $18 \pm 3 \mathrm{mmol} / \mathrm{g} \mathrm{VSS} \cdot$ day. In the absence of sulfate, no sulfide production was observed $(<2.5 \mathrm{mmol} / \mathrm{g} \mathrm{VSS} \cdot$ day $)$. The following sulfide production activities (in $\mathrm{mmol} / \mathrm{g}$ VSS·day) were measured when substrates were added: citrate $(59 \pm 9)$, formate $(50 \pm 7)$, acetate $(58 \pm 8)$, propionate $(76 \pm$ $21)$, butyrate $(33 \pm 17)$, and lactate $(116 \pm 22)$. The activity was highest with lactate, while the activity with butyrate was lowest.

The effect of sulfate on citrate conversion by sludge $R$ was determined. Rapid growth and citrate conversion was observed both in the presence (not shown) and in the absence of sulfate (Fig. 1). In both cases, acetate and formate were formed as main products. The incubations were continued, and after 2 weeks, products were analyzed again. In the incubation without sulfate, still, $19.5 \mathrm{mM}$ acetate was present, while in the incubation with sulfate, the acetate concentration had decreased to $8.5 \mathrm{mM}$. In this latter incubation, the sulfide concentration was about $18 \mathrm{mM}$ (results not shown).

Serial dilutions of sludges $\mathrm{R}$ and $\mathrm{S}$ were made in media with citrate as substrate. Sludge $\mathrm{R}$ showed growth with citrate till the $10^{5}$ dilution, while sludge $\mathrm{S}$ showed growth till the $10^{7}$ dilution. The VSS content of sludge $\mathrm{R}$ and $\mathrm{S}$ was $3 \%$ and $0.2 \%(w / v)$, respectively. This shows that the 


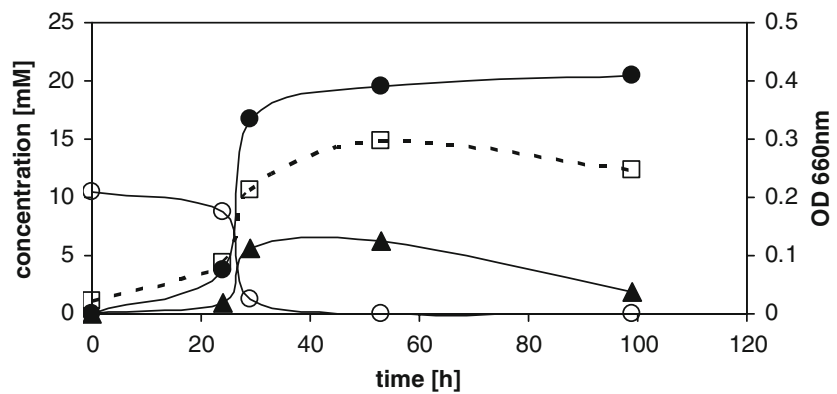

Fig. 1 Citrate degradation and product formation in media without sulfate inoculated with sludge R. In the presence of sulfate, the pattern was similar. Symbols: citrate $(\circ)$, acetate $(\bullet)$, formate $(\boldsymbol{\Delta})$, and optical density $(O D)$ at $660 \mathrm{~nm}(\square)$

relative number of citrate-degrading bacteria in sludge $\mathrm{S}$ is about 1,000 times higher than in sludge $\mathrm{R}$. The cell numbers enumerated in the dilutions in media with and without sulfate were the same. The results that were obtained in these initial studies indicated that citrate was not a direct substrate for sulfate reducers, but that citrate was first fermented, and that the fermentation products were the substrates for the sulfate-reducing bacteria. As the sulfate-reducing bacteria of the inoculum were analyzed previously (Dar et al. 2007), we focused our further research on bacteria responsible for citrate fermentation.

\section{Properties of isolated strains}

Upon microscopic observation of sludge $\mathrm{R}$ and sludge $\mathrm{S}$ and the enrichment of sludge $\mathrm{R}$ in media with citrate, coccoid cells were observed which formed twisted chains. Two citrate-fermenting bacteria were isolated: strain R201 from sludge $\mathrm{R}$ and strain 101 from sludge $\mathrm{S}$. The two strains were coccoid, but strain S101 was somewhat smaller in size than strain R201. Both strain R210 and strain S101 degraded citrate mainly to acetate and formate (Table 1 and Table 2). Strain S101 formed less formate than strain R210, but it formed some hydrogen. The substrate spectrum of the two strains was different. Strain R210 was able to ferment sugars to acetate, formate, ethanol, and lactate. Lactate was not degraded by this strain. By contrast, strain S101 did not ferment sugars but was able to ferment lactate and some other organic acids to acetate, formate, propionate, and hydrogen. Taking into account the expected formation of bicarbonate, the carbon and electron balances fitted rather well with the expected balances.

Strain R210 and strain S101 did not show growth by respiration. Both strains formed formate as a main product of citrate fermentation. However, strain S101 formed less formate in the presence of nitrate or crotonate. With these electron acceptors, about $4 \mathrm{mM}$ formate was formed during growth with $10 \mathrm{mM}$ citrate, while, in the controls, about $5.6 \mathrm{mM}$ was formed. Strain S101 was able to grow with
Table 1 Substrate utilization, growth as indicated by the optical density (OD), and product formation by strain R 210

\begin{tabular}{lccccc}
\hline & Formate & Acetate & Ethanol & Lactate & OD 660 \\
\hline No Substrate & & $<0.5$ & & & $<0.02$ \\
10 citrate & 8 & 20.5 & & & 0.71 \\
& 8 & 20.5 & & & 0.60 \\
20 malate & 18.9 & 9.5 & 10 & & 0.41 \\
& 16.9 & 8.6 & 9.8 & & 0.34 \\
20 pyruvate & 15.9 & 18.5 & 1 & & 0.36 \\
& 15.6 & 18.4 & 2.3 & & 0.41 \\
10 glucose & 6.8 & 2.3 & 4.5 & 12.4 & 0.71 \\
& 5.7 & 2.1 & 4.6 & 9.9 & 0.67 \\
10 fructose & 7.4 & 2.6 & 5.3 & 12.2 & 0.69 \\
10 mannitol & 14 & 2 & 12.9 & 0.2 & 0.70 \\
10 arabinose & 12.9 & 7.6 & 7.5 & 0 & 0.49 \\
10 mannose & 7.3 & 2.6 & 5.3 & 11.1 & 0.79 \\
5 maltose & 8.8 & 3.3 & 6 & 8.4 & 0.78 \\
5 cellobiose & 13.5 & 5.8 & 8.7 & 3.2 & 0.19 \\
5 sucrose & 6.5 & 2.4 & 4.8 & 10.6 & 0.72 \\
\hline
\end{tabular}

Cultures were inoculated with a citrate-grown culture $(1 \%$ inoculum size) and incubated statically at $30^{\circ} \mathrm{C}$. The concentrations of compounds are in millimolar $(\mathrm{mM})$

fumarate. This compound was fermented to mainly formate, acetate, and propionate. When strain S101 was grown with a mixture of citrate and fumarate, the concentration of products was similar to the sum of products formed with citrate and fumarate, separately. Oxygen was not used by the strains, but they could be grown (two transfers) in nitrogen-flushed media in which the reductant and sulfur source sodium sulfide was replaced by sodium sulfate. Growth in sulfide-reduced media under air was possible but not when the cultures were shaken.

Comparative analysis of the 16S rRNA gene sequences of the two strains showed that strain R210 was affiliated to members of the genus Trichococcus, while strain S101 was affiliated to members of the genus Veillonella (Fig. 2). Strain R210 was closest related to Trichococcus pasteurii $(99.5 \%$ rRNA gene sequence similarity). The closest relative of strain S101 was Veillonella montepellierensis with an rRNA gene sequence similarity of $96.7 \%$. Unfortunately, strain S101 was lost upon storage. Strain R210 is deposited in the German collection of microorganisms and cell cultures (DSMZ) as Trichococcus sp. R210 (accession number DSM 22150).

\section{Discussion}

Citrate is clearly not the direct substrate for the sulfatereducing bacteria in the bioreactor that was studied. Recently, (Gámez et al. 2008) found a rapid fermentation 
Table 2 Substrate utilization, growth as indicated by the optical density (OD), and product formation by strain S101

Cultures were inoculated with a citrate-grown culture $(1 \%$ inoculum size) and incubated statically at $30^{\circ} \mathrm{C}$. The concentrations of compounds are in millimolar (mM)

\begin{tabular}{llcccc}
\hline & Formate & Acetate & Propionate & Hydrogen & OD 660 \\
\hline No substrate & & $<0.5$ & & & $<0.02$ \\
10 citrate & 5 & 20.7 & 0 & ND & 0.30 \\
& 4.7 & 20.4 & 0 & 0.3 & 0.30 \\
20 malate & 2.1 & 7.9 & 12.4 & ND & 0.28 \\
& 2 & 8.2 & 13.6 & 0.0 & 0.22 \\
20 pyruvate & 9.2 & 17.3 & 1.8 & ND & 0.39 \\
& 7.4 & 14.4 & 1.6 & 0.15 & 0.34 \\
20 fumarate & 2.4 & 8.1 & 11.5 & 0 & 0.31 \\
25 lactate & 4.4 & 11.8 & 13.8 & 3.2 & 0.36 \\
\hline
\end{tabular}

of citrate by sulfate-reducing and methanogenic sludges. In our study, citrate is first fermented to mainly acetate and formate, and the sulfate-reducing bacteria subsequently use these compounds as substrates. Sludge taken from the bioreactor had a high sulfate reduction activity with several organic compounds, including formate, acetate, propionate, and lactate. The actual rate of sulfate reduction in the bioreactor at the time of sampling was about $4 \mathrm{mmol}$ sulfate/g VSS·day. The high sulfate reduction rates with the different substrates suggest that the sludge in the reactor could accommodate higher loading rates. However, our activity tests were done at low initial sulfide concentrations. It might be that at the ambient sulfide concentrations of about $10 \mathrm{mM}$, sulfate reduction rates are lower.

Citrate can be fermented in different ways leading to the formation of a variety of products including formate, acetate, propionate, and succinate (Antranikian and Giffhorn 1987; Bott 1997). The two bacteria that we have isolated formed mainly acetate, formate, and presumably, bicarbonate from citrate. The two strains were able to ferment a set of others substrates as well. Strain R210 fermented sugars. With these substrates, it formed, besides acetate and formate, also ethanol and lactate as products. Strain S101 was not able to grow with sugars, but it was able to ferment some substrates, including lactate and malate, forming propionate as product.
The products that are formed by the two strains are direct substrates for the sulfate-reducing bacteria that were previously detected in the sludge that was used to start up the bioreactor (Dar et al. 2007). This may have been beneficial for the rapid start-up of the process.

Strain R210 was a Trichococcus strain. (Scheff et al. 1984) isolated a filamentous bacterium from bulking sludge. This bacterium was described as Trichococcus flocculifomis and is able to grow with citrate, pyruvate, and a variety of sugars and polyols. Other Trichococcus species have been described like T. pasteurii (former Lactosphaera pasteurii) and Trichococcus palustris (former Ruminococcus palustris; Liu et al. 2002; Janssen et al. 1995b; Zhilina et al. 1995). There are differences in the substrate spectrum of the different Trichococcus species, but the pattern of fermentation products that we obtained with strain R210 for citrate fermentation and sugar fermentation is characteristic for Trichococcus species. Strain S101 was closest related to $V$. montepellierensis; the rRNA gene sequence similarity was $96.7 \%$. V. montepellierensis was isolated from clinical samples (Jumas-Bilak et al. 2004). It is able to ferment lactate and succinate to propionate, while it does not ferment sugars. Citrate was not tested as substrate of that strain. In general, members of the genus Veillonella ferment lactate, but they are unable to ferment sugars. The
Fig. 2 Neighbor-joining tree based on nearly complete $16 \mathrm{~S}$ ribosomal RNA gene sequences showing the phylogenetic affiliation of strain R210 and S101. The bar indicates $1 \%$ sequence difference

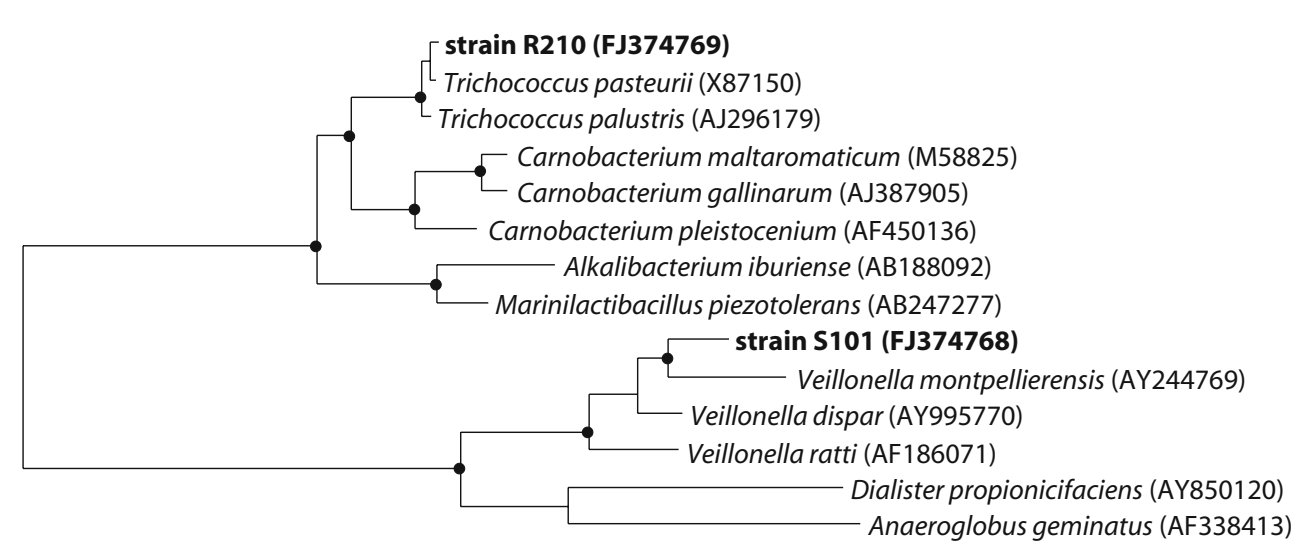

0.10 
substrate spectrum of strain S101 is similar as described for other Veillonella species, though citrate utilization was rarely tested (Kolenbrander 1992). However, Veillonella alcalescens is able to ferment citrate (De Vries et al. 1977).

The substrate spectrum of the two citrate-fermenting bacteria is rather complementary. By the combined activity of these two bacteria, a wide variety of substrates is fermented to products that are excellent substrates for the sulfate-reducing bacteria present in the sludge. In this way, complex waste streams represent and excellent source of electron donors for sulfate reduction in industrial processes. Interestingly, lactate can be fermented by strain S101 and can be degraded by a number of sulfate reducers. As shown by (Laanbroek et al. 1983), the lactate concentration and the prevailing conditions determine which of the bacteria preferentially degrades lactate.

Acknowledgments We thank the Technology Foundation STW, Applied Science Division of the Netherlands Science Foundation NWO, Chemical Sciences (CW) of NWO, and the technology program Economy Ecology Technology for financial support of our research.

Open Access This article is distributed under the terms of the Creative Commons Attribution Noncommercial License which permits any noncommercial use, distribution, and reproduction in any medium, provided the original author(s) and source are credited.

\section{References}

Antranikian A, Giffhorn F (1987) Citrate metabolism in anaerobic bacteria. FEMS Microbiol Lett 46:175-198

Bott M (1997) Anaerobic citrate metabolism and its regulation in enterobacteria. Arch Microbiol 167:78-88

Buisman CJN, Stams AJM, Meijer H, Lettinga G (1989) Sulfur and sulfate reduction with acetate and propionate in an aerobic biotechnological process for sulfide removal. Appl Microbiol Biotechnol 32:363-370

Dar S, Stams AJM, Kuenen JG, Muyzer G (2007) Coexistence of physiologically similar sulfate reducing bacteria in a full-scale sulfidogenic bioreactor fed with a single organic electron donor. Appl Microbiol Biotechnol 75:1463-1472

De Vries W, Rietveld-Struijk RM, Stouthamer AH (1977) ATP formation associated with fumarate and nitrate reduction in growing cultures of Veillonella alcalescens. Antonie Van Leeuwenhoek 43:153167

Gámez VM, Sierra-Alvarez R, Waltz RJ, Field JA (2008) Anaerobic degradation of citrate under sulfate reducing and methanogenic conditions. Biodegradation. doi:10.1007/s10532-008-9239-6

Hansen TA (1994) Metabolism of sulfate-reducing prokaryotes. Antonie Van Leeuwenhoek 66:165-185

Hulshoff Pol LW, Lens PNL, Weijma J, Stams AJM (2001) New developments in reactor and process technology for sulfate reduction. Water Sci Technol 44(8):67-76

Janssen AJH, Sleyster R, Van der Kaa C, Jochemsen A, Bontsema J, Lettinga G (1995a) Biological sulphide oxidation in a fed-batch reactor. Biotechnol Bioeng 47:327-333

Janssen PH, Evers S, Rainey FA, Weiss N, Ludwig W, Harfoot CG, Schink B (1995b) Lactosphaera gen. nov., a new genus of lactic acid bacteria, and transfer of Ruminococcus pasteurii Schink 1984 to Lactosphaera pasteurii comb. nov. Int J Syst Bacteriol 45:565-571

Janssen AJH, Ruitenberg R, Buisman CJN (2001) Industrial applications of new sulphur biotechnology. Water Sci Technol 44(8):85-90

Johnson DB (2000) Biological removal of sulfurous compounds from inorganic wastewaters. In: Lens PNL, Hulshoff Pol LW (eds) Environmental Technologies. International Association on Water Quality, London, pp 175-206

Jumas-Bilak E, Carlier J-P, Jean-Pierre H, Teyssier C, Gay B, Campos J, Marchandin H (2004) Veillonella montpellierensis sp. nov., a novel, anaerobic, Gram-negative coccus isolated from human clinical samples. Int J Syst Evol Microbiol 54:1311-1316

Kolenbrander P (1992) The genus Veillonella. In: Balows A, Trüper HG, Dworkin M, Harder W, Schleifer KH (eds) The prokaryotes, 2nd edn. Springer, New York, pp 1022-1040

Laanbroek HJ, Geerligs HJ, Peijnenburg AACM, Siesling J (1983) Competition for L-lactate between Desulfovibrio, Veillonella, and Acetobacterium species isolated from anaerobic intertidal sediments. Microb Ecol 9:341-354

Lang E, Lang H (1972) Spezifische Farbreaktion zum direkten Nachweis der Ameisensäure. Fresenius J Anal Chem 260:8-10

Lens PNL, Visser A, Janssen AJH, Hulshoff Pol LW, Lettinga G (1998) Biotechnological treatment of sulfate-rich wastewaters. Crit Rev Environ Sci Technol 28:41-88

Liu JR, Tanner RS, Schumann P, Weiss N, McKenzie CA, Janssen PH, Seviour EM, Lawson PA, Allen TD, Seviour RJ (2002) Emended description of the genus Trichococcus, description of Trichococcus collinsii sp. nov., and reclassification of Lactosphaera pasteurii as Trichococcus pasteurii comb. nov. and of Ruminococcus palustris as Trichococcus palustris comb. nov. in the low-G $+\mathrm{C}$ gram-positive bacteria. Int J Syst Evol Microbiol 52:1113-1126

López-Cortés A, Fardeau ML, Fauque G, Joulian C, Ollivier B (2006) Reclassification of the sulfate- and nitrate-reducing bacterium Desulfovibrio vulgaris subsp. oxamicus as Desulfovibrio oxamicus sp. nov., comb. nov. Int J Syst Evol Microbiol 56:1495-1499

Ludwig W, Strunk O, Westram R, Richter L, Meier H, Yadhukumar, Buchner A, Lai T, Steppi S, Jobb G, Förster W, Brettske I, Gerber S, Ginhart AW, Gross O, Grumann S, Hermann S, Jost R, König A, Liss T, Lüssmann R, May M, Nonhoff B, Reichel B, Strehlow R, Stamatakis A, Stuckmann N, Vilbig A, Lenke M, Ludwig T, Bode A, Schleifer KH (2004) ARB: a software environment for sequence data. Nucleic Acids Res 32:1363-1371

Muyzer G, Stams AJM (2008) The ecology and biotechnology of sulphate-reducing bacteria. Nat Rev Microbiol 6:441-454

Muyzer G, Teske A, Wirsen CO, Jannasch HW (1995) Phylogenetic relationships of Thiomicrospira species and their identification in deep-sea hydrothermal vent samples by denaturing gradient gel electrophoresis of $16 \mathrm{~S}$ rDNA fragments. Arch Microbiol 164:165-172

Oude Elferink SJWH, Visser A, Hulshoff Pol LW, Stams AJM (1994) Sulfate reduction in methanogenic bioreactors. FEMS Microbiol Rev 15:119-136

Oude Elferink SJWH, Akkermans-van Vliet WM, Bogte JJ, Stams AJM (1999) Desulfobacca acetoxidans gen. nov. sp. nov., a novel acetate-degrading sulfate reducer isolated from sulfidogenic sludge. Int J Syst Bacteriol 49:345-350

Rozanova EP, Nazina TN, Galushko AS (1988) Isolation of a new genus of sulfate-reducing bacteria and description of a new species of this genus, Desulfomicrobium apsheronum gen. nov., sp. nov. Microbiology 57:634-641

Scheff G, Salcher O, Lingens F (1984) Trichococcus flocculiformis gen. nov. sp. nov. A new Gram-positive filamentous bacterium isolated from bulking sludge. Appl Microbiol Biotechnol 19:114-119 
Stams AJM, van Dijk JB, Dijkema C, Plugge CM (1993) Growth of syntrophic propionate-oxidizing bacteria with fumarate in the absence of methanogenic bacteria. Appl Environ Microbiol 59:1114-1119

Stams AJM, Oude Elferink SJWH, Westermann P (2003) Metabolic interactions between methanogenic consortia and anaerobic respiring bacteria. Adv Biochem Eng Biotechnol 81:151-203

Trüper HG, Schlegel HG (1964) Sulphur metabolism in Thiorhodaceae. I. Quantitative measurements on growing cells of Chromatium okenii. Antonie Van Leeuwenhoek 30:225-238

Van Houten BHGW, Roest K, Tzeneva VA, Dijkman H, Smidt H, Stams AJM (2006) Occurrence of methanogenesis during startup of a full-scale synthesis gas fed reactor treating sulfate and metal rich wastewater. Water Res 40:553-560

Weijma J, Stams AJM (2001) Methanol conversion in high-rate anaerobic reactors. Water Sci Technol 44(8):7-14
Weijma J, Stams AJM, Hulshoff Pol LW, Lettinga G (2000) Thermophilic sulfate reduction and methanogenesis with methanol in a high rate anaerobic reactor. Biotechnol Bioeng 67:354-363

Weijma J, Gubbels F, Hulshoff Pol LW, Stams AJM, Lens PNL, Lettinga $\mathrm{G}$ (2002) Competition for $\mathrm{H}_{2}$ between sulphate reducers, methanogens and homoacetogens in a gas-lift reactor. Water Sci Technol 45(10):75-80

Widdel F, Hansen TA (1992) Dissimilatory sulfate- and sulfurreducing bacteria. In: Balows A, Trüper HG, Dworkin M, Harder W, Schleifer KH (eds) The prokaryotes, 2nd edn. Springer, New York, pp 583-624

Zhilina TN, Kotsyurbenko OR, Osipov GA, Kostrikina NA, Zavarzin GA (1995) Ruminococcus palustris sp. nov.-a psychroactive anaerobic organism from a swamp. Microbiology 64:574-579 